MARIO ROBERTO ATTANASIO JUNIOR

\title{
TEORIA CRÍTICA E DIREITO AMBIENTAL
}

\author{
Tese de Doutorado apresentada à Faculdade \\ de Direito da Universidade de São Paulo \\ como requisito para a obtenção do título de \\ doutor em Filosofia e Teoria Geral do \\ Direito. \\ Orientador: Prof. Associado Eduardo \\ Carlos Bianca Bittar \\ Área de concentração: Filosofia e Teoria \\ Geral do Direito
}

Faculdade de Direito da USP

São Paulo 